\title{
Examining the Existence of Long-run Initial Public Offering (IPO) Underperformance at Three Different Stock Exchange Markets in Japan
}

\author{
Yoshiki Shimizu \\ Washington State University \\ 570 Todd Hall, Washington State University, Pullman, Washington 99164, United States \\ E-mail: yshimizu48@gmail.com
}

Hideki Takei (Corresponding author)

Central Washington University

400 E University Way, Ellensburg, Washington 98926, United States

E-mail: hidekitakei@hotmail.com

Received: Oct. 7, 2016 Accepted: Oct. 15, 2016 Published: December 29, 2016

doi:10.5296/bms.v7i2.10126 URL: http://dx.doi.org/10.5296/bms.v7i2.10126

\begin{abstract}
This study conducted the examination of the long-run performance of IPO stocks in the Japanese market by measuring the monthly AAR/CAAR of sample IPO stocks. The study did this, so as to investigate whether IPO stocks in the Japanese market outperform in the long-run, as prior research on this phenomenon in the US market (Ritter, 1991; McDonald and Fisher, 1972) had found. The finding is that on the one hand, at TOPIX and TSE-2ND, stocks IPO firms that went public during 2004 to 2011 did not underperform the market in the long-run, as the monthly CAAR of sample IPO stocks on month 36 was not statistically significant. On the other hand, the finding also reveals that at MOTHERS, IPO firms underperformed the market throughout the period between months 2 and 36, and the monthly CAAR of IPO stocks at this market was -30.08 percent on month 36 . The implication of this finding for the Efficient Market Hypothesis is that market efficiency held well at TOPIX and
\end{abstract}




\section{Macrothink}

TSE-2ND; where during the sampling period abnormal returns could not be achieved and thus the long-run IPO underperformance was unlikely to occur. On the contrary, the departure from market efficiency was observed at MOTHERS: In the long-run, IPO stocks kept experiencing negative abnormal returns, and the existence of the long-run IPO underperformance was found to be significant. Long-run IPO underperformance did not exist, with only one exception: It is only at MOTHERS that the long-run IPO underperformance was observed, whereas at TOPIX and TSE-2ND the phenomenon was not observed.

Keywords: IPO, Japan, Stock Market 


\section{Introduction}

The overarching aim of this study is to explore the existence of long-run Initial Public Offering (IPO) underperformance at three different stock exchange markets in Japan. Long-run IPO underperformance refers to a phenomenon that occurs when IPO stocks underperform in the long-run compared to other non-IPO stocks that have been traded in the market for a long time. Pieces of research have found that the performance of IPO stocks, measured by the cumulative abnormal return of the stocks, underperform in the market for a certain period of time after going public (Ritter, 1991; Jain and Kini, 1994; Teoh et al., 1998). This also contradicts the proposition of the Efficient Market Hypothesis by Fama (1969) which suggests that the market is efficient, and thereby there is no chance for investors to achieve abnormal returns.

Pieces of prior research have extensively investigated the existence of the long-run IPO underperformance in the different markets such as the US market (Ritter, 1991) and Taiwanese market (Chang, 2011). However, there is not much research on this phenomenon in the Japanese market. This study uses a set of sample of 184 IPO firms that went public on stock exchange markets in Japan during the period from 2004 to 2011, in order to investigate the existence of these phenomenon in the Japanese market. The sample IPO firms are listed on the following stock exchange markets within The Tokyo Stock Exchange ${ }^{1}$ (TSE): Tokyo Stock Exchange 1st Section (TOPIX), Tokyo Stock Exchange 2nd Section (TSE-2ND), and The Market of The High Growth and Emerging Stocks (MOTHERS).

To investigate the long-run IPO underperformance, this study examines the long-run performance of IPO stocks by following the research method developed by Ritter (1991). In following Ritter (1991), this study calculates the monthly average abnormal return and cumulative average abnormal return of sample IPO stocks for 36 consecutive months: from the event month (the first month after firms go public) to $36^{\text {th }}$ month after IPO. Subsequently, this study also conducts the t-test to investigate whether the monthly cumulative average abnormal return differs significantly from zero during 36 months of the sampling period.

\section{Literature Review}

Literature on the long-run IPO underperformance (Ritter, 1991; McDonald and Fisher, 1972; Jain and Kini, 1994; Teoh et al., 1998) provides findings of the long-run underperformance of IPOs; literature on methods (Muradoglu et al., 1998; McDonald and Fisher, 1972; Ritter, 1991) helps clarify the research methods to examine the short- and long-run return performance of IPO stocks.

\footnotetext{
${ }^{1}$ The Tokyo Stock Exchange comprises five main markets that are Tokyo Stock Exchange $1^{\text {st }}$ Section, Tokyo Stock Exchange $2^{\text {nd }}$ Section, The Market of The High-Growth and Emerging Stocks, TSE JASDAQ, and Tokyo PRO MARKET. The structure of The Tokyo Stock Exchange is described in the website: The Tokyo Stock Exchange (http://www.tse.or.jp/english/listing/b_listing/markets.html)
} 
Ritter (1991) conducted empirical research to examine the long-run performance of IPO stocks by employing the large sample number of 1,526 IPOs in the US during a period from 1975 to 1984 . He computed the benchmark-adjusted return for IPO stocks to measure the stock performance in the long-run (from the day of IPO to 36 months after IPO). The cumulative benchmark-adjusted return for IPO stocks in the aftermarket period, which is 36 months after IPOs, has the mean of -29.13 percent. He concluded from this result that IPO stocks, on average, underperform the market in the aftermarket (36 months after IPO).

In addition to the empirical test investigating the short-run performance of newly-issued stocks, McDonald and Fisher (1972) also conducted an empirical test to investigate the performance of newly-issued stocks in the long-run (from the issuance day to a year after the issuance). They employed use of the same sample of 142 newly-issued stocks used to analyze the short-run performance, and examined the performance of the stocks in the long-run. By use of excess returns of stocks, they found that the mean excess return during the period is -18.1 percent. The negative excess returns during the periods between the issuance day and a year after the issuance explains that newly-issued stocks underperform the market in the long-run (a year after the issuance).

Jain and Kini (1994) explained a possible reason why the long-run IPO underperformance occurs. They ascribed the long-run IPO underperformance to IPO firms' window-dressing activities that occur prior to making the transition from private to public. According to them, IPO firms are likely to window-dress their accounting numbers in order to attract potential investors, and "investors appear to value firms going public based on the expectation that earnings' growth will continue while in actuality the pre-IPO profit margins, on which expectations are formed, are not even sustained" (p. 1700).

In their empirical research, Jain and Kini (1994) collected a sample of 682 IPO firms during the period from 1976 to 1988 , and confirmed the difference in market-to-book (M/B) and price-to-earning (P/E) ratios of IPO firms between pre- and post-IPO period. They also found that IPO firms show higher $\mathrm{M} / \mathrm{B}$ and $\mathrm{P} / \mathrm{E}$ ratios than their industry counterparts do at the time of IPO. Hence, they concluded that the reason why IPO stocks underperform in the post-issue period is because IPO firms window-dress their accounting numbers so as to attract investors, despite the fact that the firms know that good performance would not be able to be sustained for the long-run. Therefore, window-dressing actions by IPO firms make their potential investors systematically biased: investors feel too optimistic about IPO firms' future growth potential by looking at overstated accounting numbers that do not fully explain financial situations of the firms.

Teoh et al. (1998) untangled the empirical relationship between the IPO stock return performance and the aggressiveness of IPO firms' earnings management prior to going public. They employed a sample of 1,974 U.S. IPOs during a period from 1980 to 1984, and hypothesized that there is a relationship between accounting accruals and long-term underperformance of IPO stocks. They found that the more aggressively an IPO firm does earnings management, the lower the three-year aftermarket stock return. Hence, they found a 
negative relationship between the aggressiveness of IPO firms' earnings management and the stock return performance in the aftermarket.

\section{Research Methods}

Our research question is if long-run IPO underperformance exists at stock exchange markets in Japan. Therefore, the study strives to answer the research question by conducting statistical tests on examining long-run return performances of sample IPO stocks traded at three different stock exchange markets.

The samples are Japanese firms that went public during the period from January 2004 to June 2011. All the sample firms are listed on stock exchange markets within The Tokyo Stock Exchange (TSE), the largest stock exchange market in Japan, and the number of sample IPO firms is 184. Within TSE, there are three different exchange markets where the sample IPO firms are listed; Tokyo Stock Exchange 1st Section (TOPIX), Tokyo Stock Exchange 2nd Section (TSE-2ND), and The Market of The High-Growth and Emerging Stocks. Hereafter (MOTHERS). This study conducted statistical tests to examine the short- and long-run return performances of IPO stocks, as well as to test the market efficiency of TSE during the sample period from 2004 to 2011. The collected sample firms were categorized into three groups: TOPIX, TSE 2ND, and MOTHERS.

This study collected data of 184 firms that have gone public and are listed in three different stock exchange markets within TSE: TOPIX, TSE-2ND, and MOTHERS. There are 41, 45, and 98 sample firms listed on these markets, respectively. The list of sample firms was obtained from $\mathrm{KabuWeb}^{2}$ (2014). Financial indicators that were necessary to compute the daily/monthly stock returns, abnormal returns, market returns, etc., were retrieved from Thomson Reuter's Datastream. The study collected data of sample firms' daily stock prices for 31 consecutive days, and monthly stock prices for 36 consecutive months after they went public. Along with daily/monthly stock prices of IPO firms, daily/monthly index prices of respective markets, where the stocks are traded, were also collected. This study calculated daily/monthly returns of sample IPO stocks and indices using daily/monthly stock/indices. How the returns were calculated by using the stock/indices prices is explained in the following chapter. Index prices to compare with IPO stock prices at TOPIX, TSE-2ND, and MOTHERS are TOPIX ${ }^{3}$, Tokyo Stock Exchange Second Section Stock Price Index ${ }^{4}$, and Tokyo Stock Exchange Mothers Index ${ }^{5}$. The currency of stock and index prices was denominated in Japanese Yen ( $¥)$.

\footnotetext{
${ }^{2}$ List of IPO firms that went public at TSE: http://happy.kabu-web.net/kabu_data_4.php

${ }^{3}$ Description of TOPIX: http://www.tse.or.jp/english/market/topix/topix.html\#title 1

4 Tokyo Stock Exchange Second Section Stock Price Index: http://www.tse.or.jp/english//market/topix/lineup_data/E_f_11_2nd.pdf
}

5 Tokyo Stock Exchange Mothers Index: $\underline{\text { http://www.tse.or.jp/english/market/topix/lineup_data/E_f_12_Mothers.pdf }}$ 
To examine the long-run performance of IPO stocks in the Japanese market in order to explore the existence of the long-run IPO underperformance there, this study defined 'the first month of IPO' as 'the event month,' and defined month $t(t=1,2,3, \ldots, 36)$ as ' $t$ months after IPO.' In order to detect the existence of the long-run IPO underperformance, the study examined the performance of sample IPO stocks during the period from 'the event month' to ' $36^{\text {th }}$ month after IPO.' Thus, in this study, 'the long-run period' is defined as the period from the event month to 36 months after IPO. The long-run performance of IPO stocks was measured by examining the long-run cumulative average abnormal return of IPO stocks.

\section{Results}

\subsection{Long-Run Performance of IPO stocks at TOPIX}

Table 1 reports Descriptive Statistics of the monthly cumulative abnormal return (monthly CAR) of IPO firms listed on TOPIX. Parameter $t$ in the first column in the table represents month. When $t$ is 1 , it is the first month when the IPO firms go public, and is referred to as the event month. When $t$ is 36 , it is the $36^{\text {th }}$ month after the IPO. On the event month $(t=1)$, the mean monthly CAR was positive at 1.42 percent. The median was also positive at 1.32 percent, and it was close to the value of the mean. 1 month after IPO, the firms at TOPIX had a monthly CAR of 1.42 percent per month, and thus they were likely to outperform the market. The minimum and maximum values were -10.97 percent and 20.22 percent, both of which could be considered very low/high for the initial monthly CAR. The standard deviation on the first month was 5.57 percent. While the minimum value of -10.97 percent fell within three standard deviations from the mean, the maximum value did not. Hence, the maximum monthly CAR of 20.22 percent on the first month of IPO should be considered as an outlier in this sample population.

As time went by, the mean monthly CAR fell to -4.46 percent and this value interpreted that the firms underperformed the marker in the long-run (36 months after IPO) at the mean monthly CAR of -4.46 percent. The median monthly CAR was -9.69 percent, a value lower than the value of the mean, indicating that the distribution of samples was likely to be right-skewed and that the existence of an outlier raising the value of the mean could exist. The minimum and maximum values fell/increased to -67.71 percent and 52.67 percent, and both values were too far from the value of the mean, leaving the inference that these were potentially outliers. The standard deviation statistic was 25.78 percent, and both the minimum and maximum values fell within three standard deviations from the mean. Thus, although there was a possibility to consider the values as outliers, it was not conclusive.

\subsection{Long-Run Abnormal Return and Cumulative Abnormal Return of IPO stocks at TOPIX}

Table 2 reports the monthly average abnormal return (monthly AAR) and monthly cumulative average abnormal return (monthly CAAR) of sample IPO stocks at TOPIX. The first column of the table represents the month $(t=1,2, \ldots, 36)$, and the following 3 columns report values, t-statistics, and p-values of monthly AAR, and the last 3 columns report values, t-statistics, and p-values of monthly CAAR. This study computed t-statistics of each value to examine 
whether monthly AAR/CAAR was significantly different from zero.

Throughout the period between the event month $(t=1)$ and month $36(t=36)$, none of the monthly CAARs at TOPIX were significant, because all $\mathrm{t}$-statistics fell within the lower and upper critical values at both the 90 and 95 percent significance level. Hence, there was no sufficient evidence to reject the null hypothesis that monthly CAARs were significantly different from zero in the long-run. This inferred that the market efficiency held well at TOPIX, so that investors investing in IPO stocks listed on this index were not able to achieve abnormal returns, because monthly CAARs of IPO stocks at TOPIX throughout the period (1 $\leq t \leq 36$ ) were not statistically significant.

\subsection{Long-Run Performance of IPO stocks at TSE-2 $2^{N D}$}

Table 3 reports Descriptive Statistics of the monthly cumulative abnormal return (monthly CAR) of IPO firms listed on TSE-2ND. The number of samples was 46 firms. On the event month $(t=1)$, unlike IPO firms listed on TOPIX experiencing the positive first-month monthly CAR, the IPO firms at TSE-2ND experienced the negative monthly CAR of -1.98 percent. The firms were likely to underperform the market in their first month after IPOs showed the negative CAR of -1.98 percent per month. The median monthly CAR was -2.25 percent. The minimum and maximum monthly CAR values were -14.88 percent and 18.88 percent. The standard deviation was 6.45 percent, and the maximum value of 18.88 percent did not fall within the three standard deviations from the mean, signifying the fact that this value was extreme and therefore should have been considered as an outlier.

On month $36(t=36)$, the mean fell to -4.35 percent, enabling the interpretation that the firms in TSE-2ND were likely to underperform the market in the long-run, as the value of the mean kept declining from the first month $(t=1)$. The value of the median was -4.13 percent and was similar to that of the mean. The minimum and maximum values were -50.81 percent and 76.45 percent. This indicated that there was an IPO firm whose price performance fell to -50.81 percent 36 months after an IPO, while there was another IPO firm who achieved a 76.45 percent increase in their monthly CAR. However, A 76.45 percent increase in the monthly CAR was unusual, and hence this value could be considered as a potential outlier. The standard deviation helped account for the existence of this extreme maximum value. The standard deviation on month 36 was 24.45 percent. Because the maximum value of 76.45 percent did not fall within the three standard deviations from the mean, the value should have been considered as an outlier.

\subsection{Long-Run Abnormal Return and Cumulative Abnormal Return of IPO stocks at TSE-2 $2^{N D}$}

Table 4 reports the monthly average abnormal return (monthly AAR) and monthly cumulative average abnormal return (monthly CAAR) of IPO stocks at TSE-2ND. This study computed t-statistics of each value to examine whether monthly AAR/CAAR was significantly different from zero.

On the event month $(t=1)$, the monthly CAAR was negative at -1.98 percent, and the 
t-statistic was lower than -2.0141. Thus, at a 95 percent confidence level, there was sufficient evidence to reject the null hypothesis on the event month $(t=1)$ that the monthly CAAR was significantly different from zero. This means that, on average, IPO stocks traded at TSE-2ND had the first-month negative cumulative abnormal return, and therefore, underperformed the market. From month $3(t=3)$ until month $20(t=20)$, IPO firms at TSE-2ND kept holding negative monthly CAARs with t-statistics lower than -1.6794. Thus, at a 90 percent confidence level, there was sufficient evidence to reject the null hypothesis and to support the alternative hypothesis that during period between month $3(t=3)$ and month $20(t=20)$, monthly CAARs were significantly different from zero. From month $25(t=25)$ until month $27(t=27)$, monthly CAARs were negative and significant with t-statistics lower than -1.6794 . From month $28(t=28)$ onwards, on the other hand, monthly CAARs were negative but insignificant, with t-statistics falling within the lower and upper critical values. Though the negative monthly CAARs were significant during certain periods of the month, the significant long-run IPO underperformance at TSE-2ND was not found, because in month $36(t=36)$ there was insufficient evidence to reject the null hypothesis that the monthly CAAR in this month $(t=36)$ was different from zero. Therefore, the long-run IPO underperformance at TSE-2ND was not statistically significant.

\subsection{Long-Run Performance of IPO stocks at MOTHERS}

Table 5 reports Descriptive Statistics of the monthly cumulative abnormal return (monthly CAR) of IPO firms at MOTHERS. On the event month $(t=1)$, the mean monthly CAR was negative at -0.71 percent and the median was -3.21 percent. Because the median was lower than the mean, the distribution of samples was likely to be right-skewed, implying that there was a positive extreme value raising the value of the mean. The minimum and maximum values were -23.12 percent and 43.92 percent per month, and the first month CAR of 43.92 percent seemed very high. The standard deviation statistic was 11.58 percent, and the maximum value did not fall within the three standard deviations from the mean. Thus, this maximum value of 43.92 percent on the first day abnormal return should have been considered as an outlier in this sample population. On month 36 , the mean and median fell to -30.09 percent and -32.74 percent. The minimum and maximum values were -129.01 percent and 95.29 percent. In a long run, there was an IPO firm experiencing a 129.01 percent drop in the cumulative abnormal return, while there was another IPO firm achieving a 95.29 increase in their cumulative abnormal return. The standard deviation was 39.71 percent, and the values of both minimum and maximum fell to within the three standard deviations from the mean. There is a possibility that these values could have been potential outliers, but it was not conclusive.

\subsection{Long-Run Abnormal Return and Cumulative Abnormal Return of IPO stocks at MOTHERS}

Table 6 reports the monthly average abnormal return (monthly AAR) and monthly cumulative average abnormal return (monthly CAAR) of IPO stocks at MOTHERS. This study computed t-statistics of each value to examine whether monthly AAR/CAAR was significantly different 
from zero.

On the event month $(t=1)$, the monthly CAAR was found to be insignificant, because the t-statistic was within the upper and lower critical values. Thus, there was no sufficient evidence to reject the null hypothesis that on the event month $(t=1)$ the monthly CAAR was significantly different from zero. On month $2(t=2)$, the monthly CAAR was negative and significant at the 90 percent confidence level, because the t-statistic on month 2 was lower than -1.6607. From month $3(t=3)$ onwards, the monthly CAARs were negative and found significant at a 99 percent confidence level, as the t-statistics observed between these periods were lower than -1.9847 . Thereby, there was sufficient evidence to reject the null hypothesis, and to support the alternative hypothesis stating that the CAARs observed from the month $2^{\text {nd }}$ onwards were significantly different from zero. This led to the conclusion that monthly CAARs observed from the $2^{\text {nd }}$ month after IPO $(t=2)$ were negative and statistically significant at $95(t=2)$ and $99(3 \leq t)$ percent confidence levels. This can be interpreted that IPO stocks at MOTHERS underperformed the market in the long-run, and the underperformance began from the $2^{\text {nd }}$ month $(t=2)$ after the IPO.

4.7 Comparison of Long-Run Performances of IPO stocks at TOPIX, TSE-2ND, and MOTHERS

Figure 1 exhibits and compares long-run return performances of IPO stocks at TOPIX, TSE-2ND, and MOTHERS, followed by Table 7 reporting and comparing the performances. On the event month $(t=1)$, IPO stocks at TOPIX had the positive monthly CAAR of 1.42 percent, while IPO stocks at TSE-2ND and MOTHERS had the negative CAAR of -1.98 and -0.705 percent, respectively. However, monthly CAARs on the event month $(t=1)$ of IPO stocks at TOPIX and MOTHERS were not found significant. On the other hand, the monthly CAAR on the event month $(t=1)$ at TSE-2ND was found to be significant.

On month $36(\mathrm{t}=36)$, monthly CAARs of IPO stocks at TOPIX and TSE-2ND were found to be insignificant, because t-statistics of the values were within the lower and upper critical values. At MOTHERS, except for the event month $(t=1)$, monthly CAARs were negative and significant at a 99 percent confidence level. On month $36(t=36)$, the monthly CAAR of IPO stocks listed on MOTHERS was negative at -30.08 percent. This explains that on month 36, IPO stocks at MOTHERS had an average cumulative abnormal return of -30.08 percent.

The comparison of long-run return performances of IPO stocks listed on different stock exchange markets under TSE helped find that it was only at MOTHERS that the long-run IPO underperformance occurred. At TOPIX and TSE-2ND, the long-run IPO underperformance was not observed, because there was no sufficient evidence to reject the null hypothesis that CAARs of IPO stocks at these markets were equal to zero. Therefore, the long-run IPO underperformance was found only at MOTHERS.

\section{Discussion}

The findings helped clarify the following two findings. Firstly, the long-run IPO 
underperformance was not found at TOPIX and TSE-2ND. This is inconsistent with the findings by Ritter (1991) and McDonald and Fisher (1972), and it suggests that the market efficiency held well for IPO stocks at these markets, because there was no chance for investors to achieve abnormal returns by investing in and holding IPO stocks at TOPIX and TSE- ${ }^{\mathrm{ND}}$ for the long-run. Secondly, the long-run IPO underperformance was found at MOTHERS, and this is consistent with the findings by Ritter (1991) and McDonald and Fisher (1972). From month $2(t=2)$, IPO stocks at MOTHERS started underperforming the market and on average, they had the negative CAAR of -30.09 percent in the long-run $(t=$ 36). This finding help determine a possible departure from the market efficiency at MOTHERS, where IPO stocks keep experiencing a negative abnormal return for 35 consecutive months after IPO.

\section{Conclusion}

This study conducted the examination of the long-run performance of IPO stocks in the Japanese market by measuring the monthly AAR/CAAR of sample IPO stocks. The study did this, so as to investigate whether IPO stocks in the Japanese market outperform in the long-run, as prior research on this phenomenon in the US market (Ritter, 1991; McDonald and Fisher, 1972) had found. The finding is that on the one hand, at TOPIX and TSE-2ND, stocks IPO firms that went public during 2004 to 2011 did not underperform the market in the long-run, as the monthly CAAR of sample IPO stocks on month 36 was not statistically significant. On the other hand, the finding also reveals that at MOTHERS, IPO firms underperformed the market throughout the period between months 2 and 36, and the monthly CAAR of IPO stocks at this market was -30.08 percent on month 36 . The implication of this finding for the Efficient Market Hypothesis is that market efficiency held well at TOPIX and TSE-2ND; where during the sampling period abnormal returns could not be achieved and thus the long-run IPO underperformance was unlikely to occur. On the contrary, the departure from market efficiency was observed at MOTHERS: In the long-run, IPO stocks kept experiencing negative abnormal returns, and the existence of the long-run IPO underperformance was found to be significant.

Long-run IPO underperformance did not exist, with only one exception: It is only at MOTHERS that the long-run IPO underperformance was observed, whereas at TOPIX and TSE-2ND the phenomenon was not observed.

\section{References}

CHANG, C. (2011). IPO Underpricing: A Social Comparison Perspective. International Review of Economics and Finance, 20, 367-375.

FAMA, E. (1969). Efficient Capital Markets: A Review of Theory and Empirical Work. The Journal of Finance, 25(2), 383-417

JAIN, B. \& KINI, O. (1994). The Post-Issue Operating Performance of IPO Firms. The Journal of Finance, 49(5), 1699-1726. 
KABU.WEB. (2005). Initial Public Offering Stocks (in Japanese). [ONLINE] Available from http://happy.kabu-web.net/kabu_ipo1.html. [Accessed: 10th June 2014]

KABU.WEB. (2005). List of IPO Firms in Japan during 2004 - 2014 (in Japanese). [ONLINE] Available from http://happy.kabu-web.net/kabu_data_4.php. [Accessed: 10th June 2014]

MCDONALD, G. \& FISHER, K. (1972). New-Issue Stock Price Behavior. The Journal of Finance, 27(1), 97-102.

MURADOGLU, G., AKKAYA, N., \& CHAFRA, J. (1998). The effect of the establishment of an organized exchange on weak form efficiency: the case of Istanbul Gold Exchange. The European Journal of Finance, 4, 85-92.

RITTER, J. (1991) The Long-Run Performance of Initial Public Offerings. The Journal of Finance, 46(1), 3-27.

TEOH, S., WELCH, I., \& WONG, T. (1998). Earnings Management and the Long-Run Market Performance of Initial Public Offerings. The Journal of Finance, 53(6), 1935-1974.

Tokyo Stock Exchange, Inc. (2014). Information of Initial Public Offering Companies (in Japanese). [ONLINE] Available from http://www.tse.or.jp/listing/new/index.html. [Accessed: 21st August 2014]

Tokyo Stock Exchange, Inc. (2014). Markets of TSE. [ONLINE] Available from: http://www.tse.or.jp/english/listing/b_listing/markets.html. [Accessed: 10th August 2014]

Tokyo Stock Exchange, Inc. (2014). Summary of Indices: TOPIX. [ONLINE] Available from http://www.tse.or.jp/english/market/topix/topix.html\#title_1. [Accessed: 22nd August 2014]

Tokyo Stock Exchange, Inc. (2014). Tokyo Stock Exchange Mothers Index. [ONLINE] Available from http://www.tse.or.jp/english/market/topix/lineup_data/E_f_12_Mothers.pdf. [Accessed: 22nd August 2014]

Tokyo Stock Exchange, Inc. (2014). Tokyo Stock Exchange Second Section Stock Price Index. $\quad$ [ONLINE] Available from http://www.tse.or.jp/english//market/topix/lineup_data/E_f_11_2nd.pdf. [Accessed: 22nd August 2014]

Tokyo Stock Exchange, Inc. (2014). TSE- Indices Line-up. [ONLINE] Available from: http://www.tse.or.jp/english/market/topix/index.html. [Accessed: 20th August 2014]

\section{Appendix}

Appendix 1. 
Table 1 : Descriptive Statistics of Monthly Cumulative Abnormal Return of IPO stocks at TOPIX

\begin{tabular}{cccccccc}
\hline t (month) & Range & Minimum & Maximum & Mean & Std. Error & $\begin{array}{c}\text { Std. } \\
\text { Deviation }\end{array}$ & Median \\
\hline \hline $\mathrm{t}=1$ & 0.3118 & -0.1097 & 0.2022 & 0.0142 & 0.0087 & 0.0557 & 0.0132 \\
$\mathrm{t}=6$ & 0.6061 & -0.2907 & 0.3154 & -0.0212 & 0.0193 & 0.1237 & -0.0114 \\
$\mathrm{t}=12$ & 1.0051 & -0.7018 & 0.3034 & -0.0262 & 0.0294 & 0.1881 & -0.0358 \\
$\mathrm{t}=18$ & 1.3239 & -0.7860 & 0.5379 & -0.0385 & 0.0373 & 0.2387 & -0.0579 \\
$\mathrm{t}=24$ & 1.2200 & -0.7166 & 0.5033 & -0.0549 & 0.0392 & 0.2507 & -0.0829 \\
$\mathrm{t}=30$ & 1.3516 & -0.8148 & 0.5368 & -0.0313 & 0.0401 & 0.2568 & -0.0652 \\
$\mathrm{t}=36$ & 1.2038 & -0.6771 & 0.5267 & -0.0446 & 0.0403 & 0.2578 & -0.0969
\end{tabular}

Appendix 2.

Table 2 Monthly Average Abnormal Return and Cumulative Average Abnormal Return of IPO stocks at TOPIX

\begin{tabular}{crrrrrr}
\hline $\mathbf{t}$ (month) & \multicolumn{1}{c}{ AAR } & t-stat & p-value & CAAR & t-stat & p-value \\
\hline \hline 1 & 0.0142 & 1.632 & 0.110 & 0.0142 & 1.632 & 0.110 \\
2 & -0.0120 & -1.668 & 0.103 & 0.0022 & 0.209 & 0.835 \\
3 & -0.0026 & -0.423 & 0.675 & -0.0004 & -0.031 & 0.976 \\
4 & -0.0043 & -0.722 & 0.475 & -0.0047 & -0.356 & 0.724 \\
5 & -0.0098 & -1.606 & 0.116 & -0.0144 & -0.947 & 0.349 \\
6 & -0.0068 & -0.976 & 0.335 & -0.0212 & -1.098 & 0.279 \\
7 & -0.0019 & -0.337 & 0.738 & -0.0231 & -1.207 & 0.235 \\
8 & 0.0027 & 0.393 & 0.696 & -0.0203 & -0.906 & 0.370 \\
9 & 0.0082 & 1.558 & 0.127 & -0.0122 & -0.528 & 0.600 \\
10 & 0.0058 & 0.799 & 0.429 & -0.0064 & -0.251 & 0.803 \\
11 & -0.0090 & -1.114 & 0.272 & -0.0153 & -0.571 & 0.571 \\
12 & -0.0109 & -1.145 & 0.259 & -0.0262 & -0.892 & 0.378 \\
13 & 0.0052 & 0.853 & 0.399 & -0.0210 & -0.679 & 0.501 \\
14 & -0.0128 & -2.276 & 0.028 & -0.0338 & -1.083 & 0.285 \\
15 & 0.0062 & 0.912 & 0.367 & -0.0277 & -0.856 & 0.397 \\
16 & -0.0035 & -0.487 & 0.629 & -0.0312 & -0.942 & 0.352 \\
17 & -0.0114 & -1.401 & 0.169 & -0.0426 & -1.194 & 0.240 \\
18 & 0.0041 & 0.605 & 0.548 & -0.0385 & -1.032 & 0.308 \\
19 & 0.0039 & 0.59 & 0.558 & -0.0345 & -0.892 & 0.378 \\
20 & -0.0025 & -0.346 & 0.731 & -0.0371 & -0.953 & 0.346 \\
21 & -0.0084 & -1.259 & 0.215 & -0.0455 & -1.253 & 0.217 \\
22 & -0.0049 & -0.729 & 0.470 & -0.0504 & -1.435 & 0.159 \\
23 & 0.0026 & 0.373 & 0.711 & -0.0478 & -1.286 & 0.206 \\
24 & -0.0071 & -0.767 & 0.447 & -0.0549 & -1.403 & 0.168 \\
& & & & &
\end{tabular}

*significant at $\alpha=0.1$

Appendix 3. 
Table 2 : Monthly Average Abnormal Return and Cumulative Average Abnormal Return of IPO stocks at TOPIX (cont.)

\begin{tabular}{cccrrrr}
\hline t (month) & \multicolumn{1}{c}{ AAR } & t-stat & p-value & CAAR & t-stat & p-value \\
\hline 25 & -0.0007 & -0.093 & 0.926 & -0.0556 & -1.449 & 0.155 \\
26 & 0.0014 & 0.137 & 0.892 & $-0.0542-1.325$ & 0.193 \\
27 & 0.0052 & 0.608 & 0.546 & -0.0491 & -1.24 & 0.222 \\
28 & 0.0005 & 0.076 & 0.940 & $-0.0486-1.216$ & 0.231 \\
29 & 0.0065 & 0.872 & 0.389 & $-0.0421-1.036$ & 0.306 \\
30 & 0.0108 & 1.684 & 0.100 & -0.0313 & -0.78 & 0.440 \\
31 & 0.0042 & 0.641 & 0.525 & $-0.0271-0.708$ & 0.483 \\
32 & 0.0073 & 0.934 & 0.356 & $-0.0198-0.507$ & 0.615 \\
33 & $-0.0131 *$ & -1.808 & 0.078 & $-0.0329-0.853$ & 0.399 \\
34 & $-0.0149 *$ & -1.875 & 0.068 & $-0.0478-1.166$ & 0.251 \\
35 & -0.0050 & -0.86 & 0.395 & $-0.0528-1.257$ & 0.216 \\
36 & 0.0082 & 0.953 & 0.346 & $-0.0446-1.108$ & 0.274
\end{tabular}

*significant at $\alpha=0.1$

Appendix 4.

Table 3: Descriptive Statistics of Monthly Cumulative Abnormal Return of IPO stocks at TSE-2ND

\begin{tabular}{cccccccc}
\hline t (month) & Range & Minimum & Maximum & Mean & Std. Error & $\begin{array}{c}\text { Std. } \\
\text { Deviation }\end{array}$ & Median \\
\hline \hline $\mathrm{t}=1$ & 0.3376 & -0.1488 & 0.1888 & -0.0198 & 0.0095 & 0.0645 & -0.0225 \\
$\mathrm{t}=6$ & 0.8064 & -0.2860 & 0.5204 & -0.0368 & 0.0208 & 0.1409 & -0.0226 \\
$\mathrm{t}=12$ & 0.6232 & -0.4286 & 0.1946 & -0.0771 & 0.0224 & 0.1516 & -0.0847 \\
$\mathrm{t}=18$ & 0.8235 & -0.4807 & 0.3428 & -0.0631 & 0.0280 & 0.1899 & -0.0621 \\
$\mathrm{t}=24$ & 1.4516 & -0.8161 & 0.6355 & -0.0602 & 0.0358 & 0.2430 & -0.0727 \\
$\mathrm{t}=30$ & 1.3516 & -0.6421 & 0.7094 & -0.0553 & 0.0356 & 0.2416 & -0.0738 \\
$\mathrm{t}=36$ & 1.2726 & -0.5081 & 0.7645 & -0.0435 & 0.0360 & 0.2445 & -0.0413
\end{tabular}

Appendix 5. 
Table 4 Monthly Average Abnormal Return and Cumulative Average Abnormal Return of IPO stocks at TSE $2 \mathrm{ND}$

\begin{tabular}{ccccccr}
\hline t (month) & AAR & t-stat & p-value & \multicolumn{1}{l}{ CAAR } & t-stat & p-value \\
\hline \hline 1 & $-0.0198 * *$ & -2.082 & 0.043 & $-0.0198 * *$ & -2.082 & 0.043 \\
2 & -0.0003 & -0.04 & 0.968 & -0.0201 & -1.397 & 0.169 \\
3 & -0.0117 & -1.417 & 0.164 & $-0.0318 * *$ & -1.949 & 0.058 \\
4 & -0.0048 & -0.663 & 0.511 & $-0.0366 * *$ & -2.095 & 0.042 \\
5 & -0.0037 & -0.432 & 0.668 & $-0.0403 *$ & -1.979 & 0.054 \\
6 & 0.0035 & 0.624 & 0.536 & $-0.0368 *$ & -1.772 & 0.083 \\
7 & $-0.0159 * *$ & -2.279 & 0.027 & $-0.0527 * *$ & -2.398 & 0.021 \\
8 & -0.0012 & -0.175 & 0.862 & $-0.0539 * *$ & -2.36 & 0.023 \\
9 & 0.0030 & 0.474 & 0.638 & $-0.0509 * *$ & -2.421 & 0.020 \\
10 & $-0.0114 * *$ & -2.134 & 0.038 & $-0.0622 * *$ & -2.823 & 0.007 \\
11 & $-0.0093 *$ & -1.683 & 0.099 & $-0.0715 * *$ & -3.27 & 0.002 \\
12 & -0.0056 & -0.715 & 0.478 & $-0.0771 * *$ & -3.448 & 0.001 \\
13 & 0.0022 & 0.324 & 0.747 & $-0.0749 * *$ & -3.262 & 0.002 \\
14 & -0.0029 & -0.58 & 0.565 & $-0.0778 * *$ & -3.361 & 0.002 \\
15 & 0.0007 & 0.098 & 0.922 & $-0.0771 * *$ & -3.132 & 0.003 \\
16 & 0.0016 & 0.379 & 0.706 & $-0.0756 * *$ & -3.143 & 0.003 \\
17 & 0.0095 & 1.419 & 0.163 & -0.0660 & -2.567 & 0.014 \\
18 & 0.0030 & 0.466 & 0.643 & -0.0631 & -2.253 & 0.029 \\
19 & 0.0006 & 0.129 & 0.898 & -0.0624 & -2.264 & 0.028 \\
20 & 0.0055 & 0.868 & 0.390 & -0.0569 & -1.873 & 0.068 \\
21 & 0.0082 & 1.115 & 0.271 & -0.0487 & -1.509 & 0.138 \\
22 & 0.0025 & 0.437 & 0.664 & -0.0462 & -1.38 & 0.174 \\
23 & -0.0086 & -1.103 & 0.276 & -0.0549 & -1.583 & 0.120 \\
24 & -0.0054 & -0.918 & 0.364 & -0.0602 & -1.681 & 0.100 \\
25 & -0.0052 & -0.884 & 0.382 & $-0.0655 * *$ & -1.721 & 0.092 \\
26 & -0.0066 & -1.13 & 0.265 & $-0.0721 * *$ & -1.768 & 0.084 \\
27 & 0.0023 & 0.482 & 0.632 & $-0.0698 * *$ & -1.761 & 0.085 \\
28 & 0.0062 & 0.935 & 0.355 & -0.0636 & -1.654 & 0.105 \\
29 & 0.0113 & 0.952 & 0.346 & -0.0524 & -1.509 & 0.138 \\
30 & -0.0029 & -0.571 & 0.571 & -0.0553 & -1.552 & 0.128
\end{tabular}

Appendix 6. 
Table 4: Monthly Average Abnormal Retum and Cumulative Average Abnormal Return of IPO stocks at TSE $2 \mathrm{ND}$ (cont.)

\begin{tabular}{|c|c|c|c|c|c|c|}
\hline t (month) & AAR & t-stat & p-value & CAAR & t-stat & p-value \\
\hline 31 & -0.0018 & -0.356 & 0.723 & -0.0571 & -1.559 & 0.126 \\
\hline 32 & 0.0006 & 0.15 & 0.881 & -0.0565 & -1.538 & 0.131 \\
\hline 33 & 0.0092 & 1.091 & 0.281 & -0.0474 & -1.299 & 0.200 \\
\hline 34 & 0.0007 & 0.105 & 0.916 & -0.0467 & -1.283 & 0.206 \\
\hline 35 & -0.0032 & -0.672 & 0.505 & -0.0499 & -1.352 & 0.183 \\
\hline 36 & 0.0064 & 0.901 & 0.372 & -0.0435 & -1.206 & 0.234 \\
\hline
\end{tabular}

*significant at $\alpha=0.1 * *$ significant at $\alpha=0.05$

Appendix 7.

Table 5: Descriptive Statistics of Monthly Cumulative Abnormal Return of IPO stocks at MOTHERS

\begin{tabular}{cccccccc}
\hline t (month) & Range & Minimum & Maximum & Mean & Std. Error & $\begin{array}{c}\text { Std. } \\
\text { Deviation }\end{array}$ & Median \\
\hline \hline $\mathrm{t}=1$ & 0.6705 & -0.2312 & 0.4392 & -0.0071 & 0.0119 & 0.1158 & -0.0321 \\
$\mathrm{t}=6$ & 1.1032 & -0.5560 & 0.5472 & -0.1085 & 0.0206 & 0.2009 & -0.1189 \\
$\mathrm{t}=12$ & 1.6016 & -0.9120 & 0.6897 & -0.1933 & 0.0303 & 0.2957 & -0.2105 \\
$\mathrm{t}=18$ & 1.8952 & -0.9256 & 0.9695 & -0.2251 & 0.0372 & 0.3630 & -0.2688 \\
$\mathrm{t}=24$ & 2.2177 & -1.1341 & 1.0836 & -0.2812 & 0.0409 & 0.3985 & -0.3242 \\
$\mathrm{t}=30$ & 2.0126 & -1.1799 & 0.8327 & -0.2876 & 0.0392 & 0.3818 & -0.3062 \\
$\mathrm{t}=36$ & 2.2429 & -1.2901 & 0.9529 & -0.3009 & 0.0416 & 0.3971 & -0.3274
\end{tabular}

Appendix 8. 
Table 6: Monthly Average Abnormal Return and Cumulative Average Abnormal Return of IPO stocks at MOTHERS

\begin{tabular}{|c|c|c|c|c|c|c|}
\hline t (month) & AAR & t-stat & p-value & CAAR & t-stat & p-value \\
\hline 1 & -0.0071 & -0.587 & 0.558 & -0.0071 & -0.594 & 0.554 \\
\hline 2 & $-0.0203^{* *}$ & -2.571 & 0.012 & $-0.0274^{\star}$ & -1.927 & 0.057 \\
\hline 3 & $-0.0287^{* *}$ & -3.541 & 0.001 & $-0.0561^{* \star}$ & -3.275 & 0.001 \\
\hline 4 & -0.0185 & -2.626 & 0.010 & $-0.0745^{* * *}$ & -4.142 & 0.000 \\
\hline 5 & $-0.0179^{* *}$ & -2.101 & 0.038 & $-0.0924^{\star \star \star}$ & -4.579 & 0.000 \\
\hline 6 & $-0.0160^{* *}$ & -1.992 & 0.049 & $-0.1085^{\star \star \star}$ & -5.262 & 0.000 \\
\hline 7 & $-0.0187^{* *}$ & -2.554 & 0.012 & $-0.1272^{\star \star *}$ & -5.434 & 0.000 \\
\hline 8 & $-0.0226^{* *}$ & -2.836 & 0.006 & $-0.1497^{\star \star \star}$ & -5.91 & 0.000 \\
\hline 9 & $-0.0122^{*}$ & -1.727 & 0.088 & $-0.1619^{\star \star \star}$ & -6.091 & 0.000 \\
\hline 10 & $-0.0172^{* *}$ & -2.329 & 0.022 & $-0.1791^{* * *}$ & -6.635 & 0.000 \\
\hline 11 & $-0.0201^{* \star}$ & -2.793 & 0.006 & $-0.1992^{\star \star \star}$ & -6.659 & 0.000 \\
\hline 12 & 0.0059 & 0.767 & 0.445 & $-0.1933^{\star \star \star}$ & -6.371 & 0.000 \\
\hline 13 & -0.0047 & -0.635 & 0.527 & $-0.1980^{* * *}$ & -6.026 & 0.000 \\
\hline 14 & 0.0008 & 0.094 & 0.925 & 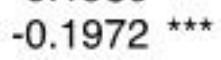 & -5.779 & 0.000 \\
\hline 15 & -0.0046 & -0.515 & 0.608 & $-0.2018^{* \star *}$ & -5.944 & 0.000 \\
\hline 16 & $-0.0133^{* *}$ & -2.004 & 0.048 & $-0.2150^{* \star *}$ & -6.172 & 0.000 \\
\hline 17 & $-0.0191^{* *}$ & -2.704 & 0.008 & $-0.2341^{\star \star \star}$ & -6.557 & 0.000 \\
\hline 18 & 0.0089 & 1.141 & 0.257 & $-0.2251^{* \star *}$ & -6.045 & 0.000 \\
\hline 19 & -0.0133 & -1.729 & 0.087 & $-0.2384^{* \star *}$ & -6.254 & 0.000 \\
\hline 20 & -0.0050 & -0.6 & 0.550 & $-0.2434^{\star \star \star \star}$ & -6.13 & 0.000 \\
\hline 21 & $-0.0184^{* *}$ & -2.435 & 0.017 & $-0.2618^{* * *}$ & -6.583 & 0.000 \\
\hline 22 & -0.0086 & -1.049 & 0.297 & $-0.2704^{\star \star \star \star}$ & -6.7 & 0.000 \\
\hline 23 & -0.0020 & -0.226 & 0.822 & $-0.2724^{\star \star \star}$ & -6.564 & 0.000 \\
\hline 24 & -0.0088 & -1.107 & 0.271 & $-0.2812^{* \star *}$ & -6.88 & 0.000 \\
\hline 25 & -0.0114 & -1.307 & 0.195 & $-0.2927^{\star \star \star}$ & -7.284 & 0.000 \\
\hline 26 & 0.0030 & 0.362 & 0.718 & $-0.2896^{\star \star \star}$ & -7.301 & 0.000 \\
\hline 27 & 0.0089 & 1.198 & 0.234 & $-0.2808^{* * *}$ & -7.015 & 0.000 \\
\hline 28 & 0.0064 & 0.796 & 0.428 & $-0.2744^{\star \star \star}$ & -7.021 & 0.000 \\
\hline 29 & -0.0105 & -1.14 & 0.257 & $-0.2848^{\star \star \star}$ & -7.111 & 0.000 \\
\hline 30 & -0.0028 & -0.298 & 0.766 & $-0.2876^{* \star *}$ & -7.342 & 0.000 \\
\hline
\end{tabular}

Appendix 9.

Table 6: Monthly Average Abnormal Return and Cumulative Average Abnormal Return of IPO stocks at MOTHERS (cont.)

\begin{tabular}{|c|c|c|c|c|c|c|}
\hline t (month) & AAR & t-stat & p-value & CAAR & t-stat & p-value \\
\hline 31 & -0.0022 & -0.293 & 0.771 & $-0.2898^{* \pi *}$ & -7.15 & 0.000 \\
\hline 32 & 0.0128 & 1.417 & 0.160 & $-0.2770^{* \star *}$ & -7.021 & 0.000 \\
\hline 33 & -0.0108 & -1.466 & 0.146 & $-0.2878^{* * *}$ & -7.116 & 0.000 \\
\hline 34 & 0.0035 & 0.405 & 0.687 & $-0.2843^{\star \star *}$ & -6.928 & 0.000 \\
\hline 35 & -0.0052 & -0.765 & 0.446 & $-0.2895^{* * *}$ & -7.092 & 0.000 \\
\hline 36 & -0.0061 & -0.704 & 0.483 & $-0.3009^{* * *}$ & -7.228 & 0.000 \\
\hline
\end{tabular}

*significant at $\alpha=0.1 * *$ significant at $\alpha=0.05 * * *$ significant at $\alpha=0.01$ 


\section{Mll Macrothink}

Business Management and Strategy

ISSN 2157-6068

2016, Vol. 7, No. 2

Appendix 10.

Figure 1 Comparison of Lond-Run Performances of IPO stocks at TOPIX, TSE-2ND, and MOTHERS.

$12.5 \%$ TOPIX MOTHERS

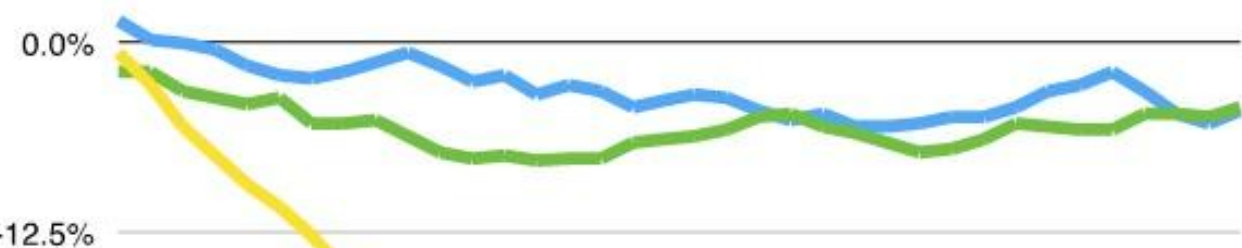

$.25 .0 \%$

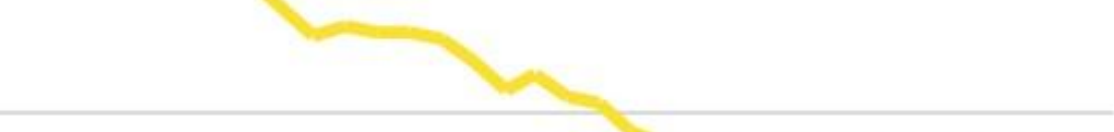

$37.5 \%$

$\begin{array}{llllllllllllllllll}1 & 3 & 5 & 7 & 9 & 11 & 13 & 15 & 17 & 19 & 21 & 23 & 25 & 27 & 29 & 31 & 33 & 35\end{array}$

Appendix 11.

Table 7: Comparison of Long-Run Return Performances of IPO stocks listed on TOPIX, TSE 2ND, and MOTHERS

\begin{tabular}{|c|c|c|c|c|c|c|}
\hline \multirow[b]{2}{*}{$t$ (months) } & \multicolumn{2}{|c|}{ TOPIX } & \multicolumn{2}{|c|}{ TSE 2ND } & \multicolumn{2}{|c|}{ MOTHERS } \\
\hline & CAAR & p-value & CAAR & p-value & CAAR & p-value \\
\hline 1 & 0.0142 & 0.110 & $-0.0198^{\star \star}$ & 0.043 & -0.0071 & 0.554 \\
\hline 6 & -0.0212 & 0.279 & $-0.0368 *$ & 0.083 & $-0.1085^{\star \star \star \star}$ & 0.000 \\
\hline 12 & -0.0262 & 0.378 & $-0.0771^{\star \star}$ & 0.001 & $-0.1933^{\star \star \star \star}$ & 0.000 \\
\hline 18 & -0.0385 & 0.308 & -0.0631 & 0.029 & $-0.2251^{\star \star \star *}$ & 0.000 \\
\hline 24 & -0.0549 & 0.168 & -0.0602 & 0.100 & $-0.2812^{* \star \star}$ & 0.000 \\
\hline 30 & -0.0313 & 0.440 & -0.0553 & 0.128 & $-0.2876^{* * \star}$ & 0.000 \\
\hline 36 & -0.0446 & 0.274 & -0.0435 & 0.234 & $-0.3009^{\star \star \star}$ & 0.000 \\
\hline
\end{tabular}

*significant at $\alpha=0.1 * *$ significant at $\alpha=0.05 * *$ significant at $\alpha=0.01$

\section{Copyright Disclaimer}

Copyright for this article is retained by Yoshiki Shimizu and Hideki Takei, with first publication rights granted to the journal.

This is an open-access article distributed under the terms and conditions of the Creative Commons Attribution license (http://creativecommons.org/licenses/by/3.0/). 